\title{
Hukum Wanita Menjadi Pemimpin Menurut Pandangan Fiqih Kontemporer
}

Muhammad Habib ${ }^{1}$, Arbianita ${ }^{2}$

Sekolah Tinggi Agama Islam Jam'iyah Mahmudiyah, Tanjung Pura

M_Habib@staijm.ac.id ${ }^{1}$

\begin{tabular}{|c|c|}
\hline INFO ARTIKEL & ABSTRAK \\
\hline $\begin{array}{l}\text { Diterima } \\
2 \text { September } 2019 \\
\text { Direvisi } \\
15 \text { November } 2019 \\
\text { Disetujui } \\
15 \text { Desember } 2019\end{array}$ & $\begin{array}{l}\text { Penjelasan mengenai kepemimpinan perempuan yang tertuang } \\
\text { dalam beberapa ayat Al-Qur'an, maka dapat dipahami bahwa } \\
\text { islam memberikan kesempatan yang sama bagi laki-laki dan } \\
\text { perempuan untuk melakukan pengabdian dalam berbagai } \\
\text { bidang, serta tidak melarang adanya kepemimpinan yang } \\
\text { dijalankan oleh perempuan, dengan berbagai potensi dan syarat }\end{array}$ \\
\hline $\begin{array}{l}\text { Kata Kunci: } \\
\text { Hukum; Wanita } \\
\text { Menjadi Pemimpin; } \\
\text { Pandangan Fiqh } \\
\text { Kontemporer }\end{array}$ & $\begin{array}{l}\text { kepemimpinan yang dimilikinya. Sebagian ulama berpendapat } \\
\text { bahwa wanita tidak boleh menjadi pemimpin, hal tersebut } \\
\text { seperti yang terdapat dalam Al-Qur'an Surat An-Nisa ayat } 34 \\
\text { Meskipun demikian, kebanyakan ulama kontemporer } \\
\text { membolehkan seorang wanita untuk menjadi pemimpin Hal ini } \\
\text { disebabkan perbedaan tafsir dalam memahami ayat tersebut. } \\
\text { Sebagaimana yang akan dibahas yakni hukum wanita menjadi } \\
\text { pemimpin menurut pandangan fiqh kontemporer. Penelitian ini } \\
\text { untuk mengetahui hukum wanita menjadi pemimpin yang dalam } \\
\text { hal ini di teliti menurut pandangan fiqh kontemporer. Dalam } \\
\text { penjelasannya ulama Kontemporer membolehkan Wanita } \\
\text { menjadi pemimpin dengan syarat tidak melanggar batasan- } \\
\text { batasan yang telah di tetapkan oleh syariatpada umumnya. } \\
\text { Pembatasan masalah dalam penelitian ini perlu dilakukan agar } \\
\text { pembahasan yang ada tidak terlalu luas dan tidak menyimpang } \\
\text { dari pokok permasalahan, disamping itu juga untuk } \\
\text { mempermudah melaksanakan penelitian. Oleh sebab itu maka } \\
\text { penulis membatasi penelitian dengan hanya membahas } \\
\text { permasalahan tentang hukum wanita menjadi pemimpin } \\
\text { menurut pandangan fiqh kontemporer pada saat sekarang ini. } \\
\text { Penelitian ini termasuk jenis penelitian kepustakaan (library } \\
\text { research), dengan menggunakan metode deskriptif analisis } \\
\text { terhadap pendapat para ulama' kontemporer, sebagai data } \\
\text { primer dan data sekundernya diambil dari kitabkitab atau buku- } \\
\text { buku yang ada kaitannya dengan masalah tersebut. Data yang } \\
\text { ditemukan adalah bahwa pada umumnya ulama-ulama } \\
\text { kontemporer, membolehkan wanita menjadi pemimpin selama } \\
\text { tidak melanggar batasan-batasan yang telah di tetapkan oleh } \\
\text { syariat. Mereka mempertimbangkan bahwa kepemimpinan } \\
\text { kepala negara dimasa sekarang ini kekuasaannya tidak sama } \\
\text { dengan seorang ratu atau khalifah di masa lalu yang dapat } \\
\text { mengambil keputusan secara langsung, beda dengan sekarang } \\
\text { yang harus musyawarah dengan para menteri ataupun staf } \\
\text { ahlinya. Dan pendapat mereka tersebut di dasari oleh dalil yang } \\
\text { terdapat dalam Al-Qur'an sura An-Namlayat } 23 \text {. }\end{array}$ \\
\hline
\end{tabular}




ABSTRACT
The explanation of women's leadership is contained in several
verses of the Qur'an, it can be understood that Islam provides equal
opportunities for men and women to do service in various fields,
and does not prohibit the existence of leadership carried out by
women, with various potentials. and leadership requirements.
Some scholars argue that women should not be leaders, this is as
contained in the Qur'an Surah An-Nisa verse 34. However, most
contemporary scholars allow a woman to be a leader. This is due
to differences in interpretation in understanding the verse. As will
be discussed, the law of women being leaders according to
contemporary fiqh views. This study is to find out the law of
women being leaders which in this case is examined according to
the contemporary fiqh view. In his explanation, contemporary
scholars allow women to become leaders on condition that they do
not violate the limits set by the Shari'a in general. Limitation of the
problem in this study needs to be done so that the discussion is not
too broad and does not deviate from the subject matter, in addition
to making it easier to carry out research. Therefore, the author
limiting the research to only discussing issues concerning the law
of women becoming leaders according to contemporary fiqh views
at this time. This research belongs to the type of library research,
using descriptive analysis methods on the opinions of
contemporary scholars, as primary data and secondary data taken
from books or books related to the problem. The data found is that
in general contemporary scholars allow women to become leaders
as long as they do not violate the limits set by the Shari'a. They
consider that the current leadership of the head of state does not
have the same power as a queen or caliph in the past who can
make decisions directly, unlike now, which must consult with
ministers or expert staff. And their opinion is based on the
arguments contained in the Qur'an sura An-Naml verse 23.

\section{Pendahuluan}

Kepemimpinan berasal dari kata "pimpin" yang berarti tuntun, bina atau bimbing. Pimpin dapat pula berarti menunjukan jalan yang baik dan benar, tetapi dapat pula berarti mengepalai pekerjaan atau kegiatan. Dengan demikian, kepemimpinan adalah hal yang berhubungan dengan proses menggerakan, memberikan tuntunan, binaan dan bimbingan, menunjukan jalan, memberi

keteladanan, mengambil resiko, mempengaruhi dan meyakinkan pihak lain, mengarahkan dan masih banyak lagi artinya.1 Riset yang telah dilakukan dalam bidang psikolog menghasilkan suatu hasil yang dapat dijadikan pijakan dalam menentukan ciri pemimpin. Seorang pemimpin biasanya memiliki intelegensia yagn lebih tinggi dibandingkan dengan pengikutnya. Kesulitan yang sangat pokok yang dihadapi oleh orang yang sangat tinggi intelegen adalah persoalan komunikasi. Seorang pemimpin dapat memotivasi para pengikutnya, sehingga para pengikutnya dapat mengerti apa yang di inginkan oleh pemimpin tersebut (Kartono, 2011).

Menjadi pemimpin bukanlah hal yang mudah. Sebab sikap-sikap kepemimpinan diperoleh bukan dari bakat sejak lahir, 
ataupun dengan mempelajarinya selama beberapa jam pertemuan. Sikap kepemimpinan merupakan sebuah proses membangun diri melalui serangkaian tempaan, sejalan dengan semakin matangnya pola pikir serta kedewasaan sikap. Sikap itu bukan sesuatu yang bisa mencapai tahap finish. Serangkaian proses yang tak pernah usai tersebut, menjurus pada satu tujuan, menjadi pemimpin yang sesungguhnya. Kepemimpinan Islam telah memberikan hak kepada perempuan seperti yang diberikan Islam kepada lakilaki, demikian pula Islam memikulkan kewajiban kepada perempuan seperti yang dipikulkan Islam kepada laki-laki, kecuali hak atau kewajiban yang dikhususkan Islam untuk laki-laki berdasarkan dalil-dalil syara'.

Dalam membicarakan tentang pemimpin wanita perempuan, menurut ajaran Islam perempuan dapat menduduki jabatan umum dalam masyarakat dan Negara, perempuan juga dengan kodratnya dapat berperan dalam kehidupan masyarakat dan Negara sesuai dengan kemampuannya ia dapat berperan serta dalam berbagai bidang baik yang bersifat material maupun spiritual. Dan yang harus diperhatikan adalah kepemimpinan yang sesuai dengan kodratnya sebagai seorang perempuan. Dalam sejarah Islam banyak contoh dari perempuan yang dapat dikemukakan diantaranya adalah istri dari Rasulullah SAW yang merupakan sebaikbaiknya contoh. Sesuai dengan sumber daya, pengetahuan, keterampilan dan kemampuannya, perempuan mampu menjadi manusia yang produktif, ia merupakan mitra sejajar dengan laki- laki, ia mendapat kebebasan melakukan apa saja asalkan tetap berada pada jalur yang syar'i. Sebagaimana dalam Firman Allah Sura AnNahl ayat 97:

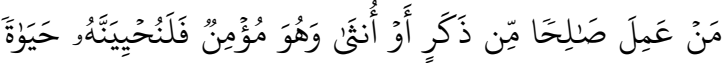

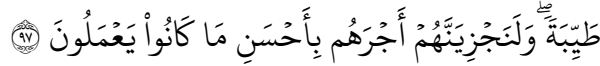

97. Barangsiapa yang mengerjakan amal saleh, baik laki-laki maupun perempuan dalam keadaan beriman, maka sesungguhnya akan Kami berikan kepadanya kehidupan yang baik dan sesungguhnya akan Kami beri balasan kepada mereka dengan pahala yang lebih baik dari apa yang telah mereka kerjakan (RI, 2018).

Dalam ayat di atas perempuan dan laki- laki secara eksplisit di dalam bekerja, karena manusia yang produktif bukan lakilaki saja. Kemudian sebagai makhluk sosial perempuan boleh bergaul dengan masyarakat, membantu yang lemah, mendidik dan mengajari orang yang ingin pintar dan pekerjaan apapun yang sesuai dengan keahliah dan kodratnya sebagai perempuan. Dengan demikian jelaslah bahwa perempuan diizinkan oleh Agama untuk memiliki peran ganda, bahkan beberapa peran sekalipum asalkan mampu membagi waktu serta selalu ingat kodratnya sebagai muslimah.

Terbatasnya jumlah pemimpin perempuan di berbagai bidang dianggap sebagai salah satu masalah penting yang harus segera diselesaikan, karena Negara kita memiliki komitmen nasional bahwa pembangunan pemberdayaan perempuan merupakan bagian integral dari pembangunan sumber daya manusia, yang dimaksudkan untuk meningkatkan status, posisi, dan kondisi perempuan agar dapat mencapai kemajuan yang setara dengan laki-laki. Peluang berkarya dan mencapai puncak karir bagi para perempuan di Indonesia telah diatur dalam banyak peraturan dan undang-undang, akan tetapi sampai saat ini masih banyak perempuan yang kurang mampu memanfaatkan peluang dan ruang yang telah disediakan, 
sehingga kepemimpinan dalam sebuah organisasi mayoritas dijalankan oleh para pria. Sebagian besar perempuan yang mampu mencapai karir puncak sebagai pimpinan di tempat kerja diyakini memiliki kelebihan jika dibandingkan dengan pemimpin pria. Kelebihan pemimpin perempuan adalah lebih resilience (ulet) dalam mengatasi tantangan dibandingkan pria dan lebih mampu mengubah tantangan menjadi peluang yang berfungsi sebagai kunci dalam mempertahankan pekerjaan dalam suatu unit usaha (Riberu, 2015).

Masalah kebebasan wanita selalu menjadi polemik dari masa ke masa bahkan sampai dengan saat ini kebebasan yang di namakan kesetaraan gender dan emansipasi wanita masih gamang Dan belum jelas. Hanya saja wanita sekarang wanita melandaskan semua ekspresi dirinya pada hak asasi, namun adanya kebebasan yang berlebihan justru membuat kondisi dan martabat wanita menjadi rendah (Muslukhafi, 2010).

Jelas sudah Islam sangat menjunjung tinggi atas hak-hak wanita, akan tetapi banyak disalah artikan sehingga berujung pelecehan terhadap wanita. Seperti halnya yang terjadi pada masa peradaban besar dunia pra Islam. Hadirnya Islam membawa rahmatalillahil'alamin (rahmat serta alam) dan tidak terkecuali bagi kebebasan wanita dalam berefektifitas sesuai yang disarankan dalam Al-Qur'an. Dan untuk lebih dapat dimengerti kesimpulan persamaan gender serta emansipasi wanita dapat diartikan yaitu : "kebebasan wanita dalam berkarya di berbagai bidang seperti bidang ekonomi, politik, sosial dan dalam hal pendidikan. Serta yang paling utama hak-hak kebebasan dari kekerasan fisik dan mental serta hakhaknya dapat disetarakan dengan laki-laki dalam ruang lingkup koridor Islam (Asror, 2006).

\section{Metode Penelitian}

Untuk mengetahui dan menjelaskan mengenai adanya segala sesuatu yang berhubungan dengan pokok permasalahan diperlukan suatu pedoman penelitian yang disebut metodologi penelitian yaitu cara melukiskan sesuatu dengan menggunakan pikiran secara seksama untuk mencapai suatu tujuan, sedangkan penelitian adalah suatu kegiataan untuk mencari, merumuskan dan menganalisa sampai menyusun laporan (Achmadi, 2007). Penelitian ini termasuk jenis penelitian kepustakaan (library research), yaitu suatu penelitian yang berusaha menggali teoriteori yang telah berkembang dalam bidang ilmu yang berkaitan dengan suatu masalah, mencari metodemetode, serta teknik penelitian baik dalam mengumpulkan data atau menganalisis penelitian yang telah digunakan oleh peneliti terdahulu, memperoleh orientasi yang lebih luas

dalam permasalahan yang dipilih serta menghindarkan terjadinya duplikasi yang tidak diinginkan dengan mengarah pada pengembangan konsep dan fakta yang ada (Nasir, 2008).

Pengumpulan data adalah prosedur yang sistematik dan standar untuk memperoleh data yang diperlukan. Untuk teknik pengumpulan data dalam jenis penelitian pustaka, langkah-langkah yang harus dilakukan pertama oleh peneliti adalah: (1) Mencari dan menemukan datadata yang berkaitan dengan pokok permasalahan. (2) Membaca dan meneliti data-data yang didapat untuk memperoleh data yang lengkap sekaligus terjamin. (3) Mencatat data secara sistematis dan konsisten. Pencatatan yang teliti begitu diperlukan karena manusia mempunyai ingatan yang sangat terbatas.

Adapun untuk teknik analisa dalam penelitian ini, sesuai dengan data yang diperoleh maka peneliti menggunakan 
teknik analisa isi atau kajian isi (content analysis), yaitu teknik atau metode yang digunakan untuk menarik kesimpulan melalui usaha menemukan karakteristik pesan dan dilakukan secara obyektif dan sistematis. Pemahaman terhadap data tersebut kemudian disajikan dengan menggunakan metode deskriptif, yaitu digunakan untuk mendiskripsikan segala

hal yang berkaitan dengan pokok pembicaraan secara sistematis, faktual dan akurat mengenai faktor-faktor dan sifatsifat serta hubungan fenomena yang diselidiki. Dari sinilah akhirnya diambil sebuah kesimpulan umum yang berasal dari data-data yang ada (Moleong, 2008).

\section{Hasil Dan Pembahasan}

\section{Pemimpin Perempuan dalam Tinjauan Islam}

Pengakuan islam terhadap adanya kepemimpinan perempuan terlihat jelas melalui penjabaran ayat surat At-Taubah, bahwa perempuan diizinkan untuk menjadi pemimpin, baik dalam bidang kehidupan duniawi, di kantor, dan di bidang-bidang lainnya. Dalam konteks peran publik menurut prinsip islam, perempuan diperbolehkan melakukan peran-peran tersebut dengan konsekuensi bahwa ia dapat dipandang mampu, dan memiliki kapasitas untuk menduduki peran sosial dan politik tersebut. Dengan kata lain, kedudukan perempuan dalam proses sistem negara-bangsa telah terbuka lebar, terutama perannya dalam masyarakat majemuk yang didasarkan pada kualitas, kapasitas, dan akseptabilitas, sekaligus tanpa melupakan fungsi kodrati perempuan sebagai sebuah keniscayaan.

Konsep kepemimpinan yang dijalankan oleh perempuan perlu dipahami secara mendalam, sehingga tidak muncul pemahaman yang kurang utuh, yaitu menganggap bahwa islam melarang para perempuan untuk menduduki jabatan sebagai pemimpin di tempatnya bekerja dan mengakibatkan munculnya anggapan bahwa islam memposisikan hak perempuan tidak sama dengan laki-laki, khususnya dalam hal pencapaian karir di tempat kerja (M, 2005).

Perempuan dan laki-laki sebenarnya memiliki kesempatan dan peluang yang sama dalam mencapai karir puncak sebagai pemimpin di tempatnya bekerja, akan tetapi karena berbagai faktor yang muncul dari para perempuan dan lingkungannya menyebabkan mereka sulit mencapai posisi tersebut, sehingga keberadaannya di berbagai bidang pekerjaan masih terbilang cukup sedikit.

Berdasarkan penjelasan mengenai kepemimpinan perempuan yang tertuang dalam beberapa ayat Al-Qur'an, maka dapat dipahami bahwa islam memberikan kesempatan yang sama bagi laki-laki dan perempuan untuk melakukan pengabdian dalam berbagai bidang, serta tidak melarang adanya kepemimpinan yang dijalankan oleh perempuan, dengan berbagai potensi dan syarat kepemimpinan yang dimilikinya. Di saat krisis kepemimpinan di suatu negara, di mana pemimpinpemimpin laki- laki sudah tidak lagi 
mendapat legitimasi dari rakyat, di saat itulah pemimpin perempuan hadir. Kepemimpinan perempuan yang bentuknya bervariasi baik itu kepala negara maupun kepala pemerintahan tingkat bawah seperti Gubernur, Bupati dan Wali Kota. Munculnya perempuan sebagai pilihan alternatif, ini dan terbukti dengan banyak perempuan yang menjadi kepala negara, perdana menteri misalnya Perdana Menteri Pakistan, Benazir Bhutto menjadi kepala negara dua periode yakni mulai tahun 1988- 1990, kemudian periode kedua tahun 1993-1996.5 Lalu di Bangladesh sudah terdapat dua pemimpin perempuan yaitu Khaleda Zia dan Sheik Hasina. Bangladesh, negara yang memisahkan diri dari Pakistan pada 1971. Khaleda Zia (19912006) dan Sheikh Hasina.yang berkuasa dua periode yakni tahun 1996-2001 dan 2009- sampai sekarang. Di Indonesia ada namanama seperti Megawati, Tri Rismaharini, Ratu Atut dan lainlain.

Kepemimpinan laki-laki tidak bisa menjamin akan membuat rakyat sejahtera, karena dalam faktanya tidak banyak pemimpinpemimpin laki-laki yang menggunakan politik sebagai senjata untuk mempertahankan kekuasaan, meraup sumberdaya alam, korupsi, dan lain-lain. Begitu juga halnya dengan kepemimpinan perempuan, banyak juga yang berbuat sama. Segala kemungkinan-kemungkinan penyelewengan kekuasaan bisa saja terjadi, karena manusia baik lakilaki maupun perempuan diliputi godaan- godaan sebagai ujiannya yang dilancarkan syetan setiap saat, sehingga manusia itu adalah mahluk yang lekat dengan lupa dan dosa, namun sebaik-baik orang yang berdosa adalah orang yang segera bertobat dan selalu mengintrospeksi dirinya untuk tindakan- tindakan di masa depan.

Nabi Muhammad tidak mewasiatkan untuk mendirikan negara Islam, juga tidak memberikan isyarat untuk memilih pemimpin setelahnya, apakah wanita atau pria. Tidak ditemukan juga dalam Al-Qur'an sistem negara yang baku, sehingga permasalahan politik adalah kebebasan individu yang dianggap sebagai alat untuk menggapai kemaslahatan yang masif bagi umat, membebaskan siapa saja untuk terjun ke dunia politik dengan memenuhi syaratsyarat dengan berpedoman teguh kepada al- Qur'an dan Sunnah.

Islam telah nempatkan hakhak perempuan pada tempatnya begitu juga dengan laki-laki. Dalam sejarahnya Islam datang ditengahtengah dekadensi moral yang tidak menganggap perempuan sebagai manusia selayaknya. Kisah ini diceritakan dalam al- Qur'an AzZuhruf ayat 17:

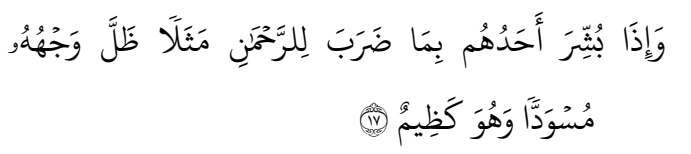

17. Padahal apabila salah seorang di antara mereka diberi kabar gembira dengan apa yang dijadikan sebagai misal bagi Allah Yang Maha Pemurah; jadilah mukanya hitam pekat sedang dia amat menahan sedih (RI, 2018). 
Maksud ayat ini ialah bilamana dia diberi kabar tentang kelahiran anaknya yang perempuan, mukanya menjadi merah padam karena malu dan dia amat marah, padahal dia sendiri mengatakan bahwa Allah mempunyai anak perempuan. Maka Islam datang, kemudian menghapuskan segala bentuk diskriminasi terhadap perempuan

2. Hukum Wanita Menjadi Pemimpin Menurut Pandangan Fiqh Kontemporer

\section{Menurut Syekh Yusuf Qardhawi Dan Dalilnya}

Syekh Yusuf Qardhawi menegaskan bahwa perempuan berhak menduduki jabatan kepala negara (riasah daulah), mufti, anggota parlemen, hak memilih dan dipilih atau posisi apapun dalam pemerintahan ataupun bekerja di sektor swasta karena sikap Islam dalam soal ini jelas bahwa wanita itu memiliki kemampuan sempurna (tamam al ahliyah).

Dalam menjelaskan persoalan ini, Qaradawi berpendapat untuk menghasilkan pemahaman yang tepat, perihal pendapat yang menyatakan di larangnya kepemimpinan perempuan berdasarkan hadist di bawah ini: "Utsman bin Haitsam dari Auf dari Hasan dari Abi Bakrah berkata: Allah memberikan manfaat kepadaku dengan sebuah kalimat yang aku dengar dari Rasulullah SAW pada hari perang jamal, setelah aku hampir membenarkan mereka (Ashabul Jamal) dan berperang bersama mereka, ketika sampai kabar kepada Rasulullah SAW bahwa bangsa Persia mengangkat putri Kisra sebagai pemimpin, beliau bersabda: Tidak akan beruntung suatu kaum yang menyerahkan urusan (pemerintahan) mereka kepada seorang wanita." (Hadist Riwayat Bukhari) (Hasyimiy, 2013).

Al-Qaradawi berpendapat dalam memahami Hadits ini terasa tepat menggunakan kaidah: "kekhususan sebab" bukan kaidah, "keumuman lafaz". Sehingga Hadits ini ditujukan spesifik kepada ratu Kisra di Persia, karena seandainya sistem pemerintahan di Persia berdasar musyawarah dan seandainya wanita yang menduduki singgasana kepemimpinan mereka seperti Golda Meir yang memimpin Israel, atau Margaret Tatcher di Inggris, Indira Gandhi di India, mungkin komentar nabi akan berbeda.

Syekh Yusuf AlQordhawi dalam hal ini kembali mempertegas bahwa kepemimpinan kepala negara dimasa sekarang ini kekuasaannya tidak sama dengan seorang ratu atau khalifah di masa lalu yang dapat mengambil keputusan secara langsung, beda dengan sekarang yang harus musyawarah dengan para menteri ataupun staf ahlinya. Hal inilah yang mendasari Qardhawi dalam memperbolehkan wanita berpolitik. Qordhawi juga menambahkan bahwa wanita boleh berpolitik dikarenakan 
pria dan wanita dalam hal mu'amalah memiliki kedudukan yang sama hal ini dikarenakan keduanya sebagai manusia mukallaf yang diberi tanggung jawab penuh untuk beribadah, menegakkan agama, menjalankan kewajiban, dan melakukan amar ma'ruf nahi munkar. Sehingga kedudukan wanita dan pria dalam hal perpolitikan adalah sejajar karena sama-sama memiliki hak memilih dan hak dipilih. Dengan alasan bahwa wanita dewasa adalah manusia mukallaf (diberi tanggung jawab) secara utuh, yang dituntut untuk beribadah kepada Allah, menegakan agama, dan berdakwah. Dan menurutnya tidak ada satupun nash Quran dan hadits yang melarang wanita untuk menduduki jabatan apapun dalam pemerintahan. seorang wanita boleh saja berkarir di dalam atau di luar rumahnya, dengan syarat tidak melanggar kode etik kesopanan dan harus mengikuti aturan yang telah ditentukan syariah, seperti: (1) Tidak mempertontonkan perhiasan dan kecantikan kepada orang lain, sehingga mengumbar nafsu, (2) Tidak boleh ada khalwat (berduaan dalam ruangan tertutup) dengan lawan jenis bukan mahram, (3) Tidak boleh melupakan tugas utamanya sebagai seorang ibu yang mendidik anak-anaknya, dan (4) Harus tetap menjaga perilaku Islami dalam berpakaian, berkata, berperilaku, dan lain-lain.

\section{Menurut Muhammad Sayid Thanthawi Dan Dalilnya.}

Menyatakan bahwa

kepemimpinan wanita dalam

posisi jabatan apapun tidak bertentangan dengan syariah. Baik sebagai kepala negara (Alwilayah Al-udzma) maupun posisi jabatan di bawahnya. Dalam fatwanya yang dikutip majalah Ad-Din wal Hayat, Tantawi menegaskan: "Wanita yang menduduki posisi jabatan kepala negara tidaklah bertentangan dengan syariah karena Al-Quran memuji wanita yang menempati posisi ini dalam sejumlah ayat tentang Ratu Balqis dari Saba.

\section{Menurut Ali Jumah Muhammad Abdul} Wahab (Mufti Mesir) Dan Dalilnya

Ali Jumah Muhammad Abdul Wahab adalah termasuk di antara ulama berpengaruh yang membolehkan wanita menjadi kepala negara dan jabatan tinggi apapun seperti hakim, menteri, anggota DPR, dan lain-lain. Namun, ia sepakat dengan Yusuf Qardhawi bahwa kedudukan Al-Imamah Al-Udzma yang membawahi seluruh umat Islam dūnia harus dipegang oleh laki-laki karena salah satu tugasnya adalah menjadi imam shalat. Ali Jumah menyatakan bahwa kepemimpinan wanita dalam berbagai posisi sudah sering terjadi dalam sejarah Islam. Tak kurang dari 90 perempuan yang pernah menjabat sebagai hakim dan kepala daerah terutama di era Khilafah Utsmaniyah. Bagi Ali Jumah, keputusan wanita untuk menempati 
jabatan publik adalah keputusan pribadi antara dirinya dan suaminya.

Dari penjabaran yang telah di jelaskan secara terperinci di atas, maka penulis dapat memperoleh hasil penelitian bahwasannyya kebanyakan ulama Kontemporer seperti Syekh Yusuf Al-Qhordowy, Muhammad Sayid Thanthawi, Ali Jumah Muhammad Abdul Wahab dalam penjelasannya membolehkan wanita menjadi pemimpin selama tidak melanggar batasan-batasan yang telah di tetapkan oleh syariat.

\section{Kesimpulan}

Hukum Wanita menjadi pemimpin menurut pandangan fiqh kontemporer seperti Syekh Yusuf Al-Qhordowy, Muhammad Sayid Thanthawi, Ali Jumah Muhammad Abdul Wahab dalam penjelasannya membolehkan wanita menjadi pemimpin selama tidak melanggar batasan-batasan yang telah di tetapkan oleh syariat. Pendapat mereka tersebut di dasari oleh dalil yang terdapat dalam Al-Qur'an sura An-Naml ayat 23.

Dalam Al-Qur'an surat An-Nisa ayat 34 ulama kontemporer berpendapat bahwa dalil tersebut belum bisa dianggap larangan dikarenakan bahwa penafsiran terhadap surat An-nisa ayat 34 menjelaskan bahwa laki-laki adalah pemimpin bagi wanita dalam lingkup keluarga atau rumah tangga. Jika ditinjau tafsir surat An-Nisa ayat 34 bahwa laki-laki adalah pemimpin wanita, bertindak sebagai orang dewasa terhadapnya, yang menguasainya, dan pendidiknya tatkala dia melakukan penyimpangan. Ulama kontemporer dalam hal ini kembali mempertegas bahwa kepemimpinan kepala negara dimasa sekarang ini kekuasaannya tidak sama dengan seorang ratu atau khalifah di masa lalu yang dapat mengambil keputusan secara langsung, beda dengan sekarang yang harus musyawarah dengan para menteri ataupun staf ahlinya. Dan pendapat tersebut di dasari karena dalil-dalil yang ada belum bisa dianggap larangan kecuali memuat setidaknya hal-hal sebagai berikut:

1. Secara redaksional nash dengan tegas mengharamkan

2. Nash dengan tegas melarangnya dengan bentuk nahi

3. Nash diikuti oleh ancaman

4. Menggunakan redaksi lain yang menurut grametika Arab menunjukkan tuntutan harus dilakukan.

\section{Bibliografi}

Achmadi, C. N. (2007). Metode Penelitian. Jakarta: Bumi Pustaka.

Asror, M. (2006). Emansipasi wanita dalam syari'at Islam. Bandung: Toha Putra.

As-Syafi'. (1983). Al-Umm Juz V. Beirut: Dar al-fikr al-'Araby.

Hasyimiy, A. S. (2013). Terjemah Muhtarul Hadist. Bandung : PT. Al Ma'arif.

Kartono, K. (2011). Pemimpin Dan Kepemimpinan,. Bandung:: Rajawali Press.

M, A. (2005). Tantangan Kepemimpinan Perempuan. Jakarta: Pena Pundi Aksara

Moleong, L. (2008). Metodologi Penelitian Kualitatif. Bandung: Remaja Karya.

Muslukhafi, S. (2010). Feminisme dan Pembudayaan Perempuan Dalam Timbangan Islam. Jakarta: Gema Insani.

Nasir, M. (2008). Metode Penelitian. Jakarta: Ghalia Indonesia. 
RI, K. A. (2018). Al-Qur'an Terjemeahan dan Transliterasi. Bandung: Mizan.

Riberu, J. (2015). Dasar-Dasar Kepemimpinan. Bandung: CV. Rajawali.
Rofiq, A. (2011). Hukum Islam di Indonesia. Jakarta: Rajawali Press.

Syarifuddin, A. (2008). Hukum Perkawinan Islam di Indonesia : Antara Fiqih Munakahat dan UU Perkawinan. Jakarta: Kencana.

\section{Copyright holder:}

Muhammad Habib, Arbianita (2020)

First publication right:

Action Research Literate

This article is licensed under:

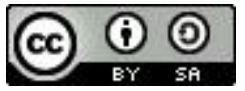

